\title{
PSYCHOLOGY
}

\section{SOCIAL AND ETHNIC IDENTITIES MANIFESTATIONS DURING UKRAINIAN EMIGRANT'S ADAPTATION}

\author{
Kovalenko A. B., \\ Doctor of psychology, Professor, \\ Ukraine, Kyiv, Head of the Department of Social Psychology, \\ Kyiv National Taras Shevchenko University \\ Bezverkha K. S., \\ Post-graduate student of the Department of Social Psychology, \\ Ukraine, Kyiv, Kyiv National Taras Shevchenko University
}

DOI: https://doi.org/10.31435/rsglobal_ijitss/31052020/7057

\section{ARTICLE INFO}

Received 25 March 2020

Accepted 08 May 2020

Published 31 May 2020

\section{KEYWORDS}

social identity, ethnic identity, adaptation, emigrants, Ukrainians.

\begin{abstract}
In the article is presented a result of researching the manifestations of social and ethnic identities in the process of adaptation of Ukrainian emigrants who live abroad ( 28 countries in general).

Emigrants have a high level of social identity, and also high levels membership satisfaction, thanks to being a member of their reference group; self-understanding and self-development, grade of belonging and the favor of informal relationships. Middle levels have the scales of in-group grade and cohesion. The low index has been revealed according to the intergroup relationships scale.

Social identity levels of emigrants with different duration of living abroad are revealed only according to the intergroup competition.

The results show the long emigrant adaptation to the new social environment until they reach the stage of activity, when, on the one hand, they feel like they are in their element, but on the other hand - they cannot forget that it is a different environment and the adaptation process has not been finished yet.
\end{abstract}

Citation: Kovalenko A. B., Bezverkha K. S. (2020) Social and Ethnic Identities Manifestations During Ukrainian Emigrant's Adaptation. International Journal of Innovative Technologies in Social Science. 4(25). doi: 10.31435/rsglobal_ijitss/31052020/7057

Copyright: (C) 2020 Kovalenko A. B., Bezverkha K. S. This is an open-access article distributed under the terms of the Creative Commons Attribution License (CC BY). The use, distribution or reproduction in other forums is permitted, provided the original author(s) or licensor are credited and that the original publication in this journal is cited, in accordance with accepted academic practice. No use, distribution or reproduction is permitted which does not comply with these terms.

Introduction. The increase in migration process all around the world has set a chain of problems related to the entrance of a personality to a new cultural and language environment.

One of the important aspects of the emigration problem is the change in a migrant identity which has been formed during the whole time of living in a native country. The migration processes widely touch upon Ukrainian society. Only after The Ukrainian Revolution of 2014 and the beginning of belligerent actions at the East of Ukraine [8] more than 150.000 Ukrainians go abroad every year [2] (Table 1).

Theoretical and empirical research models.

Social identity has been researched by $\mathrm{H}$. Tajfel (1986) as a theory of the knowledge of every separate individual on the social group they have assigned themselves to [10]. Such individual selfdetermination has emotional and evaluative meaning for a personality which, in its turn, influences a group membership. 
Table 1. Comparative statistics of the population of Ukraine from 2012 to 2020

\begin{tabular}{|l|c|c|c|}
\hline Year & As of January 1 & $\begin{array}{c}\text { Average number of people per } \\
\text { year }\end{array}$ & $\begin{array}{c}\text { Number of people who left } \\
\text { abroad }\end{array}$ \\
\hline 2020 & 41710267 & 41983564 & 273297 \\
\hline 2019 & & 42100165 & 116601 \\
\hline 2018 & & 42315836 & 215671 \\
\hline 2017 & 42502900 & 187064 \\
\hline 2016 & 42675300 & 172400 \\
\hline 2015 & 42831400 & 156100 \\
\hline 2014 & & 45496435 & 2665035 \\
\hline 2013 & 45596944 & 100509 \\
\hline 2012 & & 4 & \\
\hline \multicolumn{2}{|l|}{ The number of people who left abroad from 2012 to 2020: $\mathbf{3 8 8 6} 677$} \\
\hline
\end{tabular}

Based on our theoretical analysis, we have made an attempt to build our own structure of social identity. In doing so, we took as a basis the theoretical developments of I. O. Bondarevska, which considers social identity in terms of group similarity and group membership, where social identity reflects a sense of community with other people and includes four layers [3].

The theoretical model of social identity based on the developments of I. O. Bondarevska [3]. At the center of the model are the values that are less subject to change. After the values, there are attitudes, which are more subject to change than the values are. The third and fourth layer is the style of interpersonal interaction and behavior in a particular interaction situation, where the last one is the most subject to the change and can be influenced. The first and the second layers are combined in a meaningful (semantic) content, and the last two - in the style of interpersonal interaction in which it manifests itself.

In addition, the study found that it is appropriate to add social roles, status positions, conformity and self-concept to the model. Where the self-concept is formed as a stable integral image of one's self and is at a substantial level, which is almost unchanged, that is, at the level of values. Status positions will already appear at the level of attitudes, because the status is provided by society and forms normative behavior in accordance with the status.

Social roles are manifested at the level of interpersonal behavior styles, which a person chooses in accordance with the object of interaction. We have placed conformity on the last fourth layer of behavior in a particular situation, because only there it is visibly how conformity is manifested as an adaptation in a particularly given situation.

Ethnic identity appears evenly at all levels of the theoretical model of research as a separate component of the model.

Taking into account the results of the study by N. M. Liebiedieva, who discovered that the locus of control affects the way out of the personality from the social identity crisis, we consider it necessary to include the locus of control in the theoretical model of the social identity structure study and to substantiate this in our subsequent studies [7]. Based on theoretical analysis, we built an empirical model of social identity [1], the central place in which occupies a social identity, which includes ethnic identity.

The empirical model includes the study of such concepts as: social identity, social and psychological adaptation, Self-Concept, locus of control, values, type and evaluation of ethnic identity. Physical and psychological well-being are also important for emigrants.

Used concepts. Social identity, ethnic identity, adaptation, migrants.

In the research, we base on the developments of I. O. Bondarevskaya [3], who defines social identity as a reflection of the feeling of unity with other people, which is considered by a person from a point of view of group similarity and groups membership.

By ethnic identity we understand the definition of T. H. Stefanenko, who explores ethnic identity as an integral part of the social identity of the person, a psychological category that refers to the recognition of one's belonging to a certain ethnic community [9].

V. V. Volodko and O. A. Rovenchak define adaptation as "the process and a result of interaction, inter-adaptation and interchangeability of the unit that enters the new environment and the environment that accepts it" [4, p. 185-186]. 
To refer to the terms "migration" and "emigration", we used the definitions of Olha Rovenchak, where she stated that migration is "the intersection of an administrative border, the voluntary or involuntary spatial movement of persons or groups of persons from a place (country) of departure to a place (country) of entry in the presence or absence of legal grounds, for a fixed period or forever, which may lead to a change of permanent residence; this movement covers emigration and immigration. Accordingly, a migrant is a person who migrates.

Emigration is the crossing of the administrative border, the voluntary or forced departure of persons or groups of persons from the place (country) of residence legally or illegally, for a fixed period or forever, which implies further immigration. Accordingly, an emigrant is the person who emigrates" [4, p. 129].

The aim of research - sought to find the role of social identity in the process of adaptation of a migrant in a new environment. A migrant social identity research gives the ability to find out the way a person feels in a new environment, the way they adapt to new interpersonal relationships traditions, and also if they proceed to feel as a representative of their ethnic group or they change according to the demands of a new social environment.

\section{Research results.}

Methods and randomization of a research.

Therefore, as a methodological toolkit for research, we chose O. V. Vaskova's questionnaire of social identity (modification by A. B. Kovalenko, K. S. Bezverkha) [5], the methodology for studying the value orientations of Rokich, the Kuhn test (modification of Rumyantseva), and the scale of desire for dominance (and subordination) in the methodology of diagnosis of socio-psychological adaptation of Rogers-Diamond.

At the beginning of the research to define the reasons of residence in another country (the reasons of migration), the migrants were offered to fill in a questionnaire.

The questionnaire has also included a question concerning demographic information (age, sex, nationality, citizenship, etc.), a country of residence, the duration of living in another country, belonging to a certain religion, diaspora, an interest group. The questionnaire asked if Ukrainians keep in touch with those who stay at the motherland and with the native-born population of a recipient country, and also there were questions on language learning, supporting native and foreign traditions, and receiving a citizenship.

Sample characteristics.

85 emigrants aged 19-46 years (the average age is 28 years old) have taken part in a study, among which there are 12 men and 73 women, who have stayed abroad from a half of a year till 37 years. Most of them are Christians $(52,94 \%)$ and atheists $(9,41 \%)$.

All of the respondents are the Ukrainians by nationality and filled in the questionnaires online (96.4\%) and in-person (3.6\%) during meetings in Brno, Czech Republic (1.2\% of the total) and in Bad Dürkheim, Germany (2.4\% of the total).

Ukrainian emigrants now live in 28 different countries all around the world (Fig. 1). The biggest part or Ukrainian migrants live in the USA $(17,6 \%)$ and Poland $(16,5 \%)$. Significantly less amount - in other countries: Australia $(2,4 \%)$, Belgium $(1,2 \%)$, Canada $(2,4 \%)$, China $(1,2 \%)$, the Czech Republic (9,4\%), Denmark (4, 7\%), Egypt $(1,2 \%)$, Finland $(2,4 \%)$, France $(1,2 \%)$, Germany $(7,1 \%)$, Great Britain $(2,4 \%)$, Guinea $(1,2 \%)$, Italy $(1,2 \%)$, Jordan $(1,2 \%)$, Luxembourg $(1,2 \%)$, Netherlands $(2,4 \%)$, Qatar $(1,2 \%)$, Slovakia $(2,4 \%)$, Slovenia $(1,2 \%)$, Spain $(4,7 \%)$, Sultanate of Oman (1,2\%), Sweden (2,4\%), Switzerland $(1,2 \%)$, Turkey $(1,2 \%)$, the UAE $(5,9 \%)$.

According to the questionnaire poll results, the reasons of Ukrainian emigrants to stay abroad are the next: a job $(38,10 \%)$, studies $(26,67 \%)$, the existence of relatives, a husband or a wife, children $(20,95 \%)$, the house move together with parents in children age $(13,33 \%)$. Only $0,95 \%$ of people indicated another reason - winning the U.S. Green Card Lottery.

More than one third of the migrants $(34,12 \%)$ specified that they do not want to get a permanent residence permit to live in a foreign country, and are often thinking of coming back home. More than every tenth migrant either already has a residence permit $(11,76 \%)$ or they are in the process of getting it $(54,12 \%)$.

Among all the polled people $25,9 \%$ are members of diaspora, $74,1 \%$ do not belong to diaspora. Considering this, a diaspora membership does not affect Ukrainian emigrant's social identity, which is testified by the results of comparing two groups according to the t-test and Mann- 
Whitney U-test. F-test has turned out to be more than 0,05 , which does not give an opportunity to use the t-test, that's why Mann-Whitney U-test was utilized.

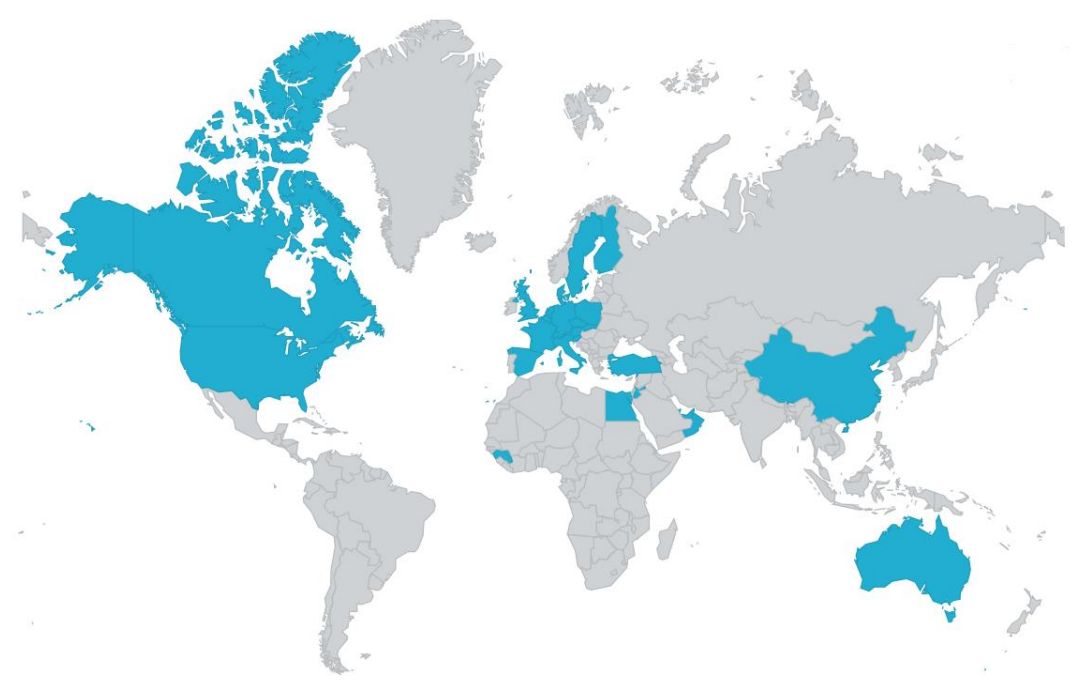

Fig. 1. Countries where Ukrainian emigrants live in

Empirical research.

Having analyzed the answers of the polled people to the questionnaire which relates to such topics as the relationships with those who stayed in Ukraine, as well as with new acquaintances in a country of migration, preservation of their own traditions and mastering new ones, conservation of groups membership in Ukraine and entering groups in another country, we found out 3 new scales: Relationships, Traditions and Belonging to a certain group. Every scale has 4 variants, according to which the respondents were divided depending on the answer to a question. Every group has been called according to its own subjective definition (Table 2).

Table 2. Scales created based on answers to questionnaire questions

\begin{tabular}{|c|c|c|c|c|c|c|}
\hline Scales & \multicolumn{2}{|c|}{ Relationships } & \multicolumn{2}{|c|}{ Traditions } & \multicolumn{2}{|c|}{$\begin{array}{l}\text { Belonging to a certain } \\
\text { group }\end{array}$} \\
\hline Questions & 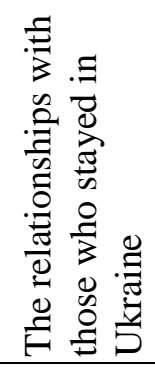 & 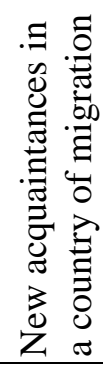 & 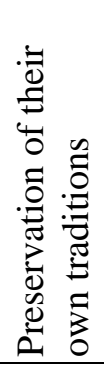 & 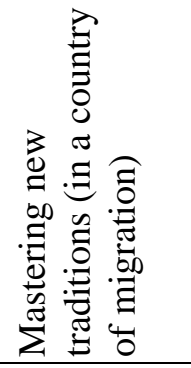 & 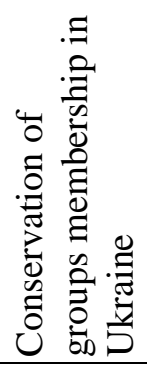 & 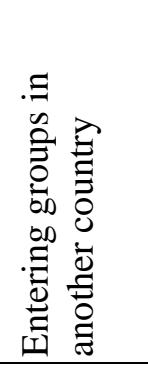 \\
\hline Yes / Yes & \multicolumn{2}{|c|}{ Integrated } & \multicolumn{2}{|c|}{$\begin{array}{l}\text { Open to new, but } \\
\text { remember old }\end{array}$} & \multicolumn{2}{|c|}{ Involved } \\
\hline Yes / No & \multicolumn{2}{|c|}{ Stucked } & \multicolumn{2}{|c|}{ Committed to its culture } & \multicolumn{2}{|c|}{$\begin{array}{l}\text { Had not managed to } \\
\text { adapt }\end{array}$} \\
\hline No / Yes & \multicolumn{2}{|c|}{ Escaped } & \multicolumn{2}{|c|}{$\begin{array}{c}\text { The one who tries to learn } \\
\text { a new culture }\end{array}$} & \multicolumn{2}{|c|}{$\begin{array}{c}\text { More socially active } \\
\text { people }\end{array}$} \\
\hline No / No & \multicolumn{2}{|c|}{ Reserved } & \multicolumn{2}{|c|}{ Torn off from culture } & \multicolumn{2}{|c|}{ Inactive people } \\
\hline
\end{tabular}

We have checked every scale on the presence of statistically-meaningful difference in social identity and adaptation of emigrants according to The Kruskal-Wallis test. We have revealed the differences in adaptability only $(\mathrm{p}=0,018)$, where those who escaped of a country have the lowest level of adaptability; the reserved people also have low level amongst these groups, but according to the methods, the level corresponds to a higher one. 
The highest level of adaptability has the polled ones who belong to groups stucked and integrated. It means that the middle level of adaptability has those who are not in touch with those who stayed in the motherland, but also have not yet established relationships with people in a new country. But at the same time, keeping in touch with those who stayed in the motherland or/and with a new environment increases the level of adaptability. Probably, supporting previous relationships a person dwells on the past and cannot integrate into a new community effectively.

According to the "tradition" scale among the emigrants' answers no statistically meaningful difference was revealed $(\mathrm{p} \geq 0,05)$. According to the "belonging to groups" scale significant differences between self-development and self-understanding scales of Social Identity questionnaire $(p=0,037)$, and between the "desire for domination" scale (a diagnostic method of socio-psychological adaptation by Diamond Rogers) $(\mathrm{p}=0,003)$ were revealed.

According to the scale "self-understanding and self-development", the average levels have socially active and inactive people. But involved and those who had not managed to adapt have high levels, that is, for them a reference group acts as a source of self-knowledge and through it they develop, so they have such a group both in their homeland and in a new environment. But those who did not have such a group, may not, do not feel that self-development through such a group.

According to the "desire for domination" scale only more socially active people are prone to subordination, while others to domination. Perhaps, exactly the feeling of having the age over a group (self-development) made a person come up with their own decision, and for the same or a similar group at a new place. The absence of such a thought about obtaining certain opportunities also made inactive people to not even try to find an interest group in a new society. And those who did not have such a group, having moved into a new environment, because of their propensity to subordination either fell under someone's influence and found a group, or basing on some of their reflections still decided to be more among people.

Using the Custom tables, we checked the stages on which stay those, who had not managed to adapt yet, and found out that the researched people equally go through the stages of euphoria and the approaching disappointment. So, indeed, because of the lack of time, adapting to a new rhythm, and new life in general, they may not have managed to find such a group.

To find out exactly the Self-Concept, we offered to the researched ones a test by Kun (modified by Rumiantseva). The results testify that the researched have mostly Reflective Self $(53,8 \%)$, but there is also a big percent of people with Social Self $(41,8 \%)$. Also only $2,2 \%$ of the researched have Problem Self and Active Self, but Material Self has not been represented by any of the respondents (Fig. 2):

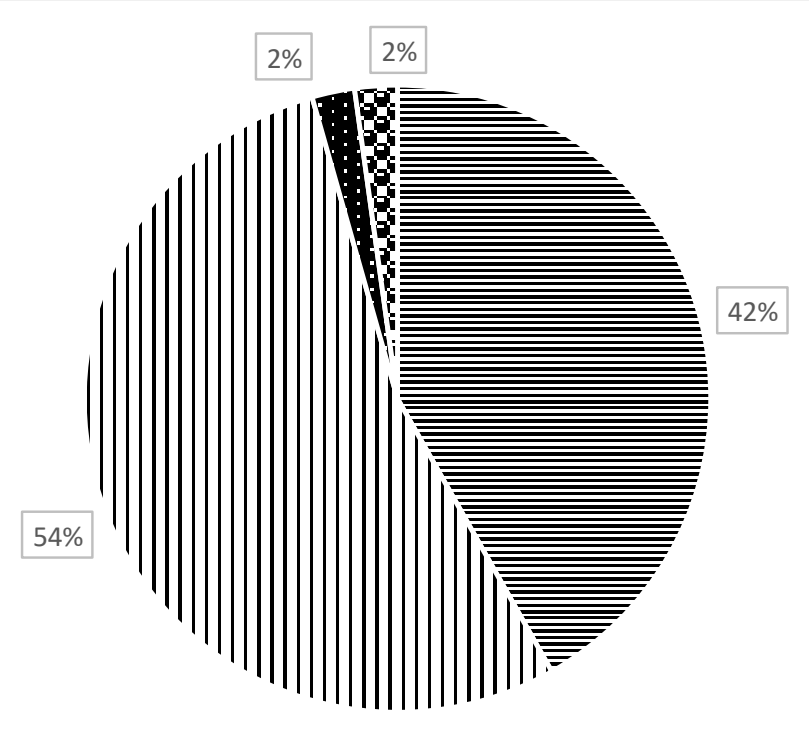

= Social Self

1. Reflective Self

- Active Self

- Problem Self

Fig. 2. The Self-Concept of Ukrainian emigrants 
Basically the social identity level we have checked using the questionnaire by $\mathrm{O}$. V. Vas'kova (modification by A. B. Kovalenko, K. S. Bezverkha), and the average method for all the respondents. It turned out that, in general, emigrants have a high level of social identity, and also high levels of membership satisfaction, self-understanding and self-development, the grade of belonging and the favor of informal relationships. The low index has been found in the intergroup relationships scale.

Thus, the Ukrainians who have migrated are really positive about their group membership, and also highly appreciate their belonging to this group. Maybe it happens because the group gives them the opportunity for self-development, self-understanding, and the favor of informal relationships. Also a person does not feel the intergroup competition.

In order to understand which reference groups exactly had chosen the respondents, we coded the answers and applied the analysis in the frequency domain (Fig. 3).

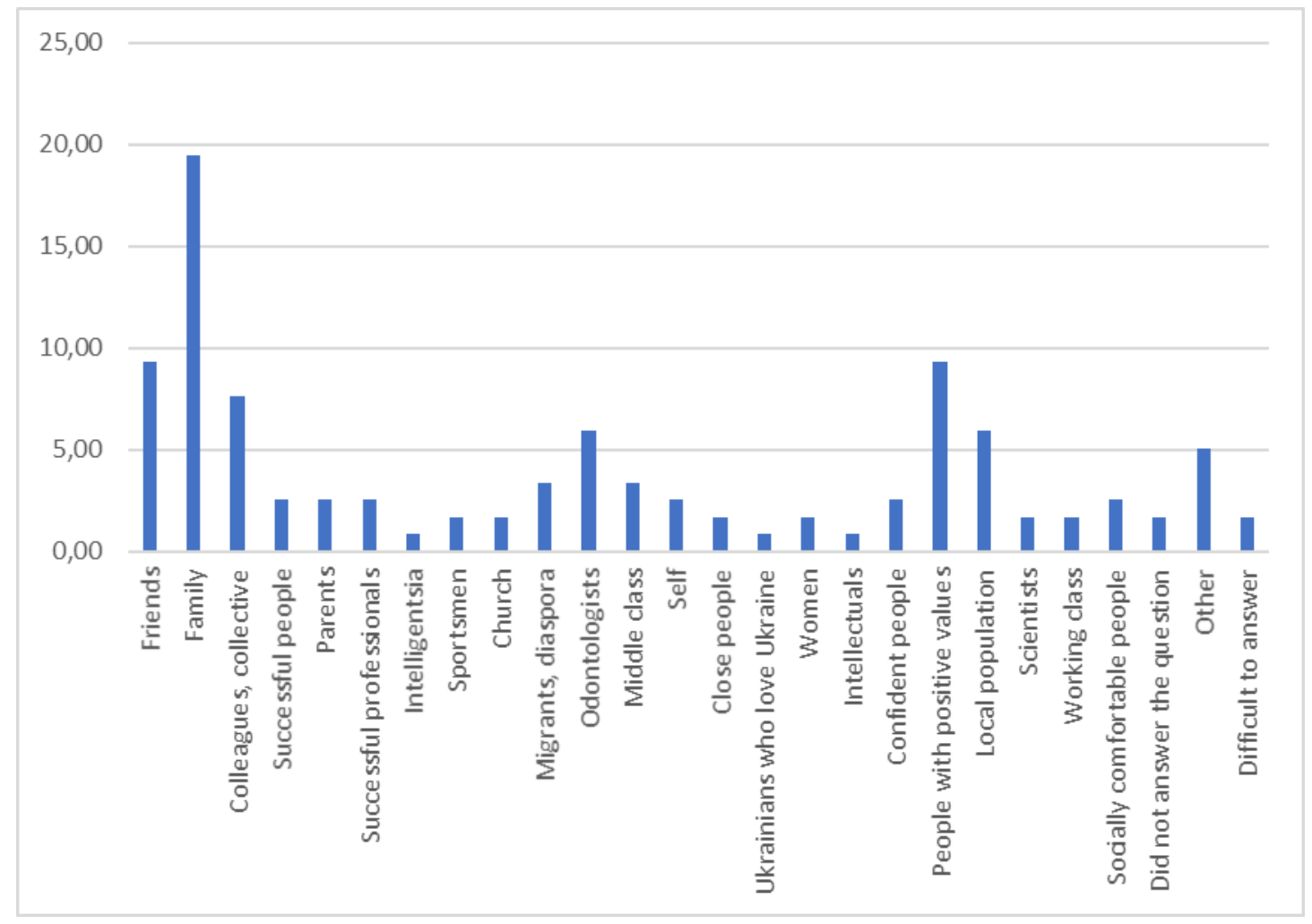

Fig. 3. Reference groups of Ukrainian emigrants (\%)

So, the Ukrainian emigrants choose their family as a reference group more often $(19,49 \%)$, people with positive (similar) values $(9,32 \%)$, friends $(9,32 \%)$, colleagues $(7,63 \%)$, representative of the local population abroad $(5,93 \%)$ and like-minded people $(5,93 \%)$. The least times people have chosen intelligentsia, Ukrainians who love Ukraine, and intellectuals.

We checked if there is a difference between the chosen groups for which we had coded the main chosen groups to get a smaller number and a bigger number of people in separate groups which would provide the relevance of doing the statistical analysis. So, we have received such as: family, friends, colleagues (groupmates), hobbies (and values), representatives of local population, likeminded people, all the others have been united. And The Kruskal-Wallis test showed that there is no statistically meaningful difference $(\mathrm{p} \geq 0,05)$. So, belonging to a particular group does not make any difference, the most important is the existence of such group.

So, in general, Ukrainian migrants are oriented towards family, people with positive (similar) values, friends, colleagues, representatives of local population abroad and like-minded people as their reference group, which gives a person the very positive meaning of belonging to it, and it is highly appreciated by a person. It may be because a group gives them an opportunity for self-development and self-understanding thanks to the favor of informal relationships. Also a person does not feel the intergroup competition. 
As we have found out during the general sampling, the levels of social identity can differ according to the duration of staying in another environment, that is why we have checked if there is a statistically meaningful difference between the levels of social identity of people who are at different stages of migration. And we have discovered that they differ only according to the intergroup competition scale due to The Kruskal-Wallis test $(\mathrm{p} \leq 0,005)$. Where the orientation stage ( 8,8 points) and fighting depression stage (6,00 points) have a low level, and all the others - a normal one.

Maybe in this period people feel that have difficulties in integration and adaptation, but they still want to enter a new community, that is why they significantly lower their grades to the questions of this scale, which leads to the underestimated level of intergroup competition.

So to look what is precisely happening to the adaptation of Ukrainian emigrants, we have calculated the average index according to the scale of diagnostic method of socio-psychological adaptation by Rogers-Diamond. The received results indicate the high levels of adaptability, accepting yourself and others, emotional comfort, inner control and domination. It means that the researched ones have a high adaptation level. It may be because the researched people stay in an environment where they develop a necessity in integration, thus in the actualization of adaptability, which increases the grades of people during the questionnaire poll.

To check if people are affected by integration and duration of staying abroad, we have applied The Kruskal-Wallis test, where we found out (Table 3 ) that the difference between migration stages exists in such scales as: adaptability $(\mathrm{p}=0,016)$, misadaptation $(\mathrm{p}=0,004)$, self-rejection $(\mathrm{p}=0,026)$, rejection of others $(\mathrm{p}=0,014)$, emotional comfort $(\mathrm{p}=0,003)$, emotional discomfort $(0,013)$, outer control $(0,030)$ and escapism $(\mathrm{p}=0,014)$.

Table 3. Levels of Types and Estimates of the Ethnic Identity of Emigrants from Ukraine in the Period of Migration

\begin{tabular}{|c|c|c|c|c|c|c|c|c|}
\hline $\begin{array}{r}\text { Types of the } \\
\text { Ethnic Identity }\end{array}$ & 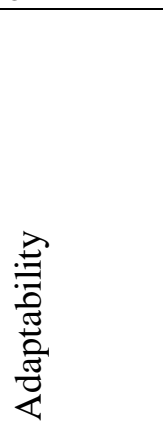 & 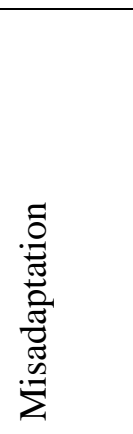 & 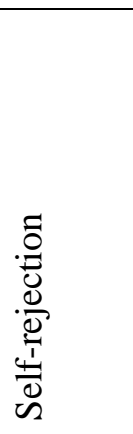 & 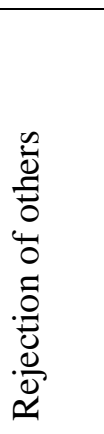 & 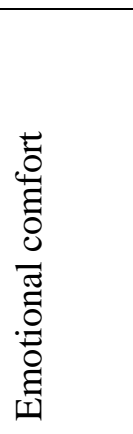 & 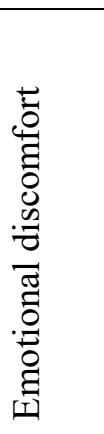 & $\begin{array}{l}\overline{0} \\
: \\
0 \\
0 \\
\overline{0} \\
\overline{0}\end{array}$ & 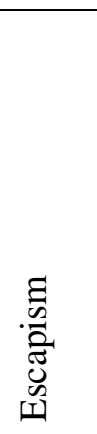 \\
\hline Euphoria & $187,77 \boldsymbol{\Lambda}$ & 89,08 & 16,00 & 18,77 & $34,38 \boldsymbol{\Lambda}$ & 18,15 & 22,31 & 16,54 \\
\hline $\begin{array}{l}\text { Approaching } \\
\text { disappointment }\end{array}$ & $172,85 \mathbf{\Delta}$ & 99,69 & 18,13 & 21,69 & $31,44 \boldsymbol{\Lambda}$ & 21,35 & 25,27 & 16,79 \\
\hline Orientation & $182,77 \boldsymbol{\Lambda}$ & 77,69 & $13,46 \boldsymbol{\nabla}$ & 17,31 & $32,62 \boldsymbol{\Delta}$ & 15,31 & 18,38 & 12,38 \\
\hline $\begin{array}{l}\text { Fighting } \\
\text { depression }\end{array}$ & $188,20 \boldsymbol{\Delta}$ & 74,00 & $12,20 \boldsymbol{\nabla}$ & 17,40 & $34,20 \boldsymbol{\Delta}$ & 14,20 & $17,80 \boldsymbol{\nabla}$ & 16,00 \\
\hline Active stage & $162,00 \mathbf{\Delta}$ & 112,00 & 21,33 & 25,00 & 23,67 & 24,17 & 25,67 & 18,00 \\
\hline
\end{tabular}

The results show that the general adaptability level of emigrants is very high, and does not differ exactly according to the methods levels, but considering the tendency to changes in grades, we can see that the level is very high at euphoria stage and is abruptly lowered at the stage of approaching disappointment. But at the next two stages it increases and gets to the maximum index at the stage of fighting depression. But then at the very last, active stage it drastically lowers again, and reaches an almost normal level, even though according to the misadaptation scale, people have the highest level at this stage.

The given result can be directly proportional to the stages and feelings of a person, who stay at this period, in which they need to adapt to new circumstances every year, so that they actualize their 
adaptability skills until they reach the active stage which allows a person to feel relatively welcome. But it still does not let to forget that it is a different environment, and sometimes, you will have to get used to it throughout the whole life.

The lowest level of rejecting oneself and others is observed at the stage of orientation and overcoming depression, at which people determine who they actually are and what they aspire to, if they want to stay. That is why they carefully treat themselves, their wishes and other people, even though on the general background, they still feel like "aliens" among others.

Even though they have increased levels of emotional comfort, except the active stage, which can witness about the fact that they are comfortable with staying in another, often better community, or that, vice versa, they set too high grades in order to feel "settled". Although at the stage of orientation and overcoming depression they still feel less emotionally comfortable, perhaps, because they do not even reflect on it, as there are more important issues to consider.

Also, the data in the table indicates that the levels of outer control differ as well, where at the stage of overcoming depression the level is lower than the average one, so that people shift the responsibility for the events that happen to them not on at the environment, but at themselves. They may feel guilty for that they cannot adapt and find their place, and that is why develops depression. And after overcoming depression the level of control flattens out and becomes normal.

The method of revealing the locus of control indicates that in general, emigrants have mostly the internal locus (13,04 points), and fewer of them have the external one (9,96 points).

So although deepening in oneself (escapism) has average levels during all the stages, but at the orientation stage it is the lowest, maybe, because at this stage people already understand that they want to stay in a new society, new country, so they do not have any time for reflecting, only for acting.

What happens to ethnic identity of Ukrainian emigrants during their adaptation, we have found out according to the average index: Ukrainian emigrants have high and very high levels of ethnic indifference and normal ethnic identity respectively, and also the low level of ethnoegoism. And also the positive estimation of ethnic identity prevails.

So, the researched people treat their nation predominantly in a positive way, as well as other nations. Sometimes they even have indistinct ethnic identity which is expressed in uncertainty or irrelevance. And the low level of ethnoegoism witnesses that people are inclined to irritation or certain pressure while chatting to representatives of other nations.

The same average tendency preserves during all the migration stages (the Kruskal-Wallis test, $\mathrm{p} \geq 0,05)$, except the ethnoisolationism scale ( $\mathrm{p}=0,030)$, which at the stages of orientation ( 7,23 points), overcoming depression ( 7,20 points) and active stages ( 8,17 points) has the lowered index. It means that people with the beginning of the orientation stage feel the complete contrast to persuasions about the advantages of their nation and are really positive about interethnic marriages, unions, etc. Maybe because at the beginning of these stages they make decision to stay in a new society.

Staying in another community in one way or another affects the level of wellbeing. According to the general physical scale and all the scales of psychological wellbeing of The short estimation of health method emigrants have low and below average levels. They are especially low according to the scales of general health and social functioning.

So, people estimate their physical health as low now, and also indicate that this state hinders them to function fully at the social level. They evaluate the vital activity subjectively low (do not feel themselves full force and energy), feel the negative impact of their emotional state and estimate their psychological health as low, including mood.

Such a result can be explained by those moods and states which accompany staying in another environment in general and the attempts to enter a new system, which you do not even know. The hypothesis about the negative subjective health evaluation because of age has not been confirmed, so the Kruskal-Wallis test has not revealed any statistically meaningful difference between age groups $(p \leq 0,05)$, but has revealed such a difference between the migration stages in the scales of the role functioning $(\mathrm{p}=0,021)$ and psychological health $(\mathrm{p}=0,006)$.

So, at the stage of approaching disappointment people subjectly feel the biggest impact of physical state while doing some work or during routine activities, but at the stages of overcoming depression and activity stage a person subjectively does not feel any influence. Perhaps, because exactly at the stage of approaching disappointment a person feels a burden and obstacles which make them review their life, that is why they are too sensitive and physical exercises do not affect their self- 
esteem in a good way. Such worsening of functioning affects psycho-emotional state as well, which is reflected in the scale of psychological health, where the lowest result, again, have the people at the stage of approaching disappointment.

At the activity stage people also give the lowest points to their psychological health, so sometimes they are depressed, lack cheerfulness, or are apathetic, etc. Maybe, because already at the activity stage people find tranquility and rest, nothing makes them lead an active lifestyle to fight against their problems, so life against the background of previous problems seems to be more boring and uninteresting.

Conclusions. At the different types of migration exist different levels of physical and psychological wellbeing, but resettlement and the ways of adaptation in a new environment significantly worsens the subjective estimation of wellbeing, to a considerable degree in role functioning and psychological health.

The positive ethnoidentity and open attitude to other nations contribute to the more effective adaptation of a person in a new environment. And also the decision of a person to stay at a new place and try to adapt has good influence on adaptation.

Orienting at the group, people look for the possibility of self-realization and self-development. A group helps to adapt in a new environment more effectively, but also an important factor is that those who keep in touch with people from their country have a higher adaptability level.

So, social identity is an important component of Ukrainians' adaptation process. Family is an important element for social identity and human adaptation in the new environment. In addition, the recipient countries should not impede, but even promote, all kinds of possible measures aimed at supporting and developing Ukrainian culture in other countries. Perhaps by funding for the study of a foreign language by Ukrainians in other countries and by the development of diasporas at the state level.

\section{REFERENCES}

1. Bezverkha K. S. Model sotsialnoi identychnosti yak mekhanizmu adaptatsii mihrantiv. Problemy osobystosti v suchasnii nautsi: rezultaty ta perspektyva doslidzhennia, 17 bereznia 2017 r.: Materialy XIX Mizhnarodnoi konferentsii molodykh vchenykh / Za red. I. V. Danyliuka, S. Yu. Pashchenko. - K.: Lohos, 2017 - S. 26-28.

2. Bezverkha K. Social Identity as the Ukrainian Migrants'Adaptation Factor in Czech Republic. Problemy osobystosti v suchasnii nautsi: rezultaty ta perspektyva doslidzhennia, 20 kvitnia 2018 r.: Materialy XX Mizhnarodnoi konferentsii molodykh naukovtsiv / Za red. I. V. Danyliuka, S. Yu. Pashchenko. -K.: Lohos, 2018 - S. 26-28.

3. Bondarevska I. Teoretychni pidkhody do vyvchennia sotsialnoi identychnosti. Sotsialna psykholohiia. Kyiv, 2011. - № 4 (48). - S. 14 - 25.

4. Volodko V.V., Rovenchak O. A. Modeli sotsiokulturnoi adaptatsii immihrantiv. Visn. Lviv. un-tu. Ser. sotsiol. - 2008. - Vyp. 2. - S. 182-210.

5. Kovalenko A. B., Bezverkha K. S. Modyfikatsiia opytuvalnyka sotsialnoi identychnosti. Ukrainskyi psykholohichnyi zhurnal: zbirnyk naukovykh prats / holovn. red. I. V. Danyliuk: KNU im. Tarasa Shevchenka. - K., 2017. - №4(6). - S. 53-65.

6. Kovalenko A. B., Bezverkha K. S. Teoretychni zasady vyznachennia struktury sotsialnoi identychnosti osobystosti. Naukovi studii iz sotsialnoi ta politychnoi psykholohii: zb. statei / NAPN Ukrainy, in-t Sotsialnoi ta politychnoi psykholohii; [redaktsiina rada: M. M. Sliusarevskyi (holova), V. H. Kremen, S. D. Maksymenko ta in.]. - Kyiv: Zoloti vorota, 2017. - vyp. 40(43) - S. 80-88.

7. Liebiedieva N. M. Vvedenye v эtnycheskuiu y kross-kulturnuiu psykholohyiu. - M.: "Kliuch-S”, 1999. - $191 \mathrm{~s}$.

8. Naselennia ta emihratsiia. Statystychna informatsiia Derzhavnoi statystychnoi sluzhby Ukrainy. Demohrafichna ta sotsialna statystyka, 2019. Dostup do dzherela: http://database.ukrcensus.gov.ua/PXWEB2007/ukr/news/op_popul.asp

9. Stefanenko T.H. Эtnopsykholohyia. 4-e yzd. yspr. y dop. - M.: Aspekt Press, 2009. - 368 s.

10. Tajfel, H. The social identity theory of intergroup behavior. In S. Worchel \& W. G. Austin (Ed.), Chicago, IL, Nelson-Hall, 1986: 7-24. 